\title{
Chlosta jako sposób wymuszania zeznań w procesie karnym miast polskich XVII-XVIII wieku
}

\author{
Prügel als Mittel zur Erzwingung von Aussagen \\ im Strafprozess der polnischen Städte XVII-XVIII Jh.
}

1. Różne sposoby wymuszania zeznań w praktyce sądów miejskich w Polsce. 2. Chłosta jako odmienny od tortur środek przymusu w postępowaniu dowodowym. 3. Cele chłosty. 4. Sposób przeprowadzania przesłuchań. 5. Chłosta $w$ trakcie procesu a wymiar kary. 6. Zniesienie tortur w $1776 \mathrm{r}$. i dalsze stosowanie chłosty wobec oskarżonych. 7. Podsumowanie.

1. Verschiedene Methoden der Zwangaussagen von den Stadtgerichten in Polen. 2. Prügel - eine Alternative zur Folter als Zwangsmittel im Beweisverfahren. 3. Ziele der Prügel. 4. Art und Weise der Vernehmung. 5. Prügel während des Prozesses und die Höhe der Strafe. 6. Beseitigung der Folter im Jahre 1776 und Fortsetzung der Prügel gegenüber den Angeklagten. 7. Resümee.

1. W dość skromnej literaturze historycznoprawnej poświęconej miejskiej procedurze sądowej wyjątkowo dużą uwage zwracano na problem wymuszania zeznań. Zajmowano się jednak wyłącznie torturami', tymczasem badania praktyki wymiaru sprawiedliwości wskazują, iż nie byl to jedyny sposób nakłaniania obwinionego, by powiedział prawdę.

Pewną formę nacisku stanowiło już samo upominanie oskarżonego, aby przyznal się do winy, nic przy tym nie ukrywając, a także straszenie go

\footnotetext{
Zob. K. B u kowsk a, Proces w prawie miejskim, [w:] Historia państwa i prawa Polski, t. II, red. J. Bardach, Warszawa 1971, s. 421-423; W. M a ise1, Tortury w praktyce sqdu kryminalnego miasta Poznania $w$ wiekach XVI-XVIII, Studia i Materiały do Dziejów Wielkopolski i Pomorza 1979, t. XIII, z. 1 (25), s. 115-125; t enże, Torture in the practice of the Poznan criminal Court, 16th-18th cent, [w:] Humanitarian Traditions of the Polish Criminal Procedure. (On the History of the Torture Abolition and Free Expression in the Polish Criminal Procedure), red. S. Waltoś, Warszawa-Kraków 1983, s. 11-22; W. U r u s z$\mathrm{czak}$, The torture in practice of the Wisinicz Criminal Court in the seventeenth century, [w:] Humanitarian Traditions..., s. 23-28; t e nż e, Proces czarownicy w Nowym Sqzzu w 1670 roku. $Z$ badań nad miejskim procesem karnym czasów nowożytnych, [w:] Historia prawa. Historia kultury. Liber Memorialis Vitoldo Maisel dedicatus, red. E. Borkowska-Bagieńska, H. Olszewski, Poznan 1994, s. 199-202.
} 
wizją boskiego sądu; wydaje się jednak, że według współczesnych, działania takie nie uchodziły za środek przymusu, zaś zeznania postraszonego aresztanta uważano za całkowicie dobrowolne ${ }^{2}$. Podobnie lagodnym rodzajem presji było pozbawienie wolności, które - jak się okazuje - stosowano nie tylko jako karę i środek prewencyjny. Oto w $1703 \mathrm{r}$. w maleńkiej Nowej Górze sąd, nie mając pewnych dowodów, nie zdecydowal się zdać oskarżonego na tormenta, lecz odroczyl sprawę o tydzień, a na ten czas oddal złoczyńcę do wiezzienia cięższego [...], aby sie mógl dobrowolnie przyproszony przyznać. ${ }^{3}$. Takie świadome wykorzystywanie aresztu jako "zachęty" do złożenia szczerych zeznań było chyba jednak wyjątkowe4. Znamy co prawda podobne decyzje z Krakowa, ale kilkakrotnie orzekane tam przetrzymania oskarżonych $w$ więzieniu miały na nich wymusić nie tyle zeznania, ile raczej zwrot skradzionych przedmiotów i wynagrodzenie szkóds.

2. Istniał jednak jeszcze jeden środek przymusu, niewątpliwie już wiążący się z zadawaniem cierpień. Zdarzało się bowiem, że sądy miejskie nakazywały wychłostanie oskarżonego, które miało skłonić go do złożenia zeznań. O stosowaniu chłosty wobec obwinionych pisał swego czasu Bartłomiej Groicki i w ślad za Jodokiem Damhouderem zalecal, by zloczyńca przed innemi mekami naprzód byl bit miotlami ${ }^{6}$. Najwyraźniej więc traktowal on owe rózgi jako wstęp do właściwych tortur. W praktyce jednak chłosta występowała nie jako jeden $\mathrm{z}$ etapów dręczenia przestępcy, poprzedzający

${ }^{2}$ Por. przykład takiego przesłuchania z Nowej Góry. W 1695 r. przyprowadzono przed tamtejszy sąd Szymona Wandeczkę. Zanim zaczęto zadawać pytania, przywiedziono mu [...] przykazanie Boże przed oczy i przypomniano, aby na sumnienie swoje pomniac, szczerze $i$ dobrowolnie, co winien przyznal, nic na się nie tajac, przypominając, że kto inszy lepiej [je]go spowiedzi wyslucha (rkps w Archiwum Państwowym w Krakowie [dalej: APKr.]; Inwentarz tymczasowy [dalej: IT], sygn. $229 \mathrm{~g}$, s. 45-46).

${ }^{3}$ APKr. IT $229 \mathrm{~g}$, s. 107.

- Być może również zastosowany w $1698 \mathrm{r}$. areszt miał skruszyć oskarżonego. Nowogórski urząd miejski przed ostatecznym rozpoznaniem sprawy obwinionego destinowal naprzód na więzienie trzech niedziel. $\mathrm{Z}$ żalem stwierdzono potem, że owo pozbawienie wolności $\mathrm{w}$ istocie nie bylo mu więzieniem $i$ ciężkościq, ale swawolq, albowiem nie sluchając nakazania, miasto więzienia po gospodach kieliszki wytrącal, miasto żalu za grzech swój w więzieniu, krzykal i okna wybil (APKr. IT, 229g, s. 70). W tym samym miasteczku w 1754 r. odnotowano, że stawiony do sądu oskarżony, na którego mocno [...] instygowano, rad nierad przyznal się do kradzieży (APKr. IT 229h, s. 18).

s APKr., Akta miasta Krakowa [dalej: AMKr.], sygn. 870, s. 63 (1698); APKr. AMKr. 871, s. 77 (1700), 78 (1700).

${ }^{6}$ B. Groicki, Porzadek sqdów i spraw miejskich w Koronie Polskiej, wyd. K. Koranyi, Warszawa 1953, s. 196. 
rozciąganie członków czy przypiekanie, lecz jako niezależny sposób pozyskiwania zeznan' ${ }^{7}$. Zdarzało się zresztą, że sąd oddalał zgłoszony przez delatora wniosek o zastosowanie tortur, a poprzestawal na wymierzeniu delikwentowi plag8.

O wykorzystywaniu chłosty $w$ postępowaniu dowodowym już kiedyś wspominaliśmy, potrafiliśmy jednak wówczas podać jedynie przykłady $\mathrm{z}$ osiemnastowiecznego Krakowa ${ }^{9}$. Tymczasem okazuje się, że podobnie postępowaly sądy $w$ innych miastach. Przeshuchania za pomocą rózg prowadzono więc $w$ sąsiadujących $z$ Krakowem - Kazimierzu ${ }^{10}$ i Kleparzu ${ }^{11}$, ale $\mathrm{i} w$ bardziej odległych miejscowościach: Nowej Górze ${ }^{12}$, Tarnowie ${ }^{13}$, a także w Przemyślu ${ }^{14}$. Chyba jednak nie wszędzie. W zachowanych księgach sądowych Nowego Sącza, Dobczyc, Miechowa i Żywca nieraz napotykamy na informacje o zastosowaniu tortur ${ }^{15}$, zupełnie natomiast brakuje wzmianek o poddawaniu oskarżonych chłoście. Nie jest więc wykluczone, że w niektórych miejscowościach ten łagodniejszy sposób wymuszania zeznań w ogóle się nie przyjąl.

Warto też zauważyć, że wszystkie znane nam przekazy źródłowe informujące o chłoście stosowanej wobec obwinionych pochodzą z końca XVII oraz

\footnotetext{
${ }^{7}$ Najprawdopodobniej zaliczany jednak do „korporalnych konfesat". Tak oto w $1771 \mathrm{r}$. w Tarnowie tamtejszy sąd miejski dla powzięcia większej wiadomości skazał oskarżoną o cudzolóstwo kobiete na korporalne inkwizycje w postaci chłosty (rkps w Muzeum Okręgowym w Tarnowie [dalej: MTarn.], sygn. MT-H 505, k. 96v.). Por. też MTarn. MT-H 505, k. 66 (1763).

${ }^{\text {в }}$ Por. APKr. AMKr. 878, s. 97 (1744); APKr. AMKr. 880, s. 139 (1751). W tym ostatnim przypadku oskarżyciele próbowali apelować od decyzji sądu.

${ }^{9} \mathrm{M}$. M i k ołajczyk, Z dziejów wymuszania zeznań w Polsce (na podstawie praktyki krakowskiego sqdu miejskiego w II polowie XVIII wieku), Problemy Prawa Karnego [Katowice] 1995, t. XXI, red. K. Marszal, s. 89-94.

${ }^{10}$ Zob. np. APKr., Akta miasta Kazimierza [dalej: AMKaz.], sygn. K 275, s. 30-31 (1779), 206 (1784); APKr. AMKaz. K. 278, s. 28 (1790).

$"$ Zob. APKr., Akta miasta Kleparza [dalej: AMKlep.], sygn. KL 69, s. 347 (1776); APKr. AMKlep. KL 70, s. 27-28 (1783).

12 Zob. APKr. IT 229h, s. $17(1751 / 1752), 18$ (1754).

${ }_{13}$ Np. MTam. MT-H 505, k. 33v. (1756), 65v.-66 (1763).

${ }_{14}$ Por. notatkę z 1734 r.: Pytany po plagach od sadu nakazanych, jeżeli nie kradl...? (rkps w Archiwum Państwowym w Przemyślu [dalej: APPrzem.], Archiwum miasta Przemyśla [dalej: AMPrzem.], sygn. 85, s. 38).

is Por. np. APKr., Akta depozytowe [dalej: AD], sygn. 67 (Nowy Sącz), s. 78 (1597), 196-202 (1628), 319-320 (1645); APKr. AD 116 (Nowy Sącz), s. 71-72 (1657), 253-256 (1664), 355-356 (1668), 449-451 (1676), 520-521 (1684); rkps w Archiwum Państwowym w Krakowie, Oddział na Wawelu [dalej: APKr./W.], AD 67 (Dobczyce), s. 33-35 (1701), 60 (1704), 108 (1736); rkps w Bibliotece Jagiellońskiej w Krakowie [dalej: BJ], sygn. 86 (Miechów), k. 33-36 (1607), 64-65 (1652), 93v.-94 (1735); Akta spraw zloczyńców miasta Żywca, [w:] S. Szczotk a, Materialy do dziejów zbójnictwa góralskiego z lat 1589-1782, Lublin-Lódź 1952, s. $15-16$ (nr 1, 1589 r.), 25 (nr 11, 1595 r.), 55 (nr 45, 1618 r.), $91-93$ (nr 72, 1625 r.).
} 
z XVIII stulecia. W Krakowie na pewno wykorzystywano ów środek przymusu $w$ latach dziewięćdziesiątych XVII ${ }^{16}{ }^{16}$; ponieważ jednak nie zachowały się tamtejsze księgi spraw kryminalnych z lat $1634-1678^{17}$, nie można wykluczyć, że w mieście tym już nieco wcześniej posługiwano się rózgami, by zachęcić oskarżonych do zlożenia zeznań ${ }^{18}$. O takiej metodzie prowadzenia przesłuchań milczą natomiast akta z XVI i początków XVII stulecia $^{19}$. Dane $\mathrm{z}$ innych miast dotyczą wyłącznie XVIII $\mathrm{w}^{20}$, zaś w niezbyt odległej od Krakowa Nowej Górze pierwszy znany przypadek użycia chłosty w celach dowodowych odnotowano dopiero w roku $1752^{21}$. Jest więc całkiem prawdopodobne, że i tam, gdzie stosowano ową lagodniejszą wersję korporalnych konfesat, pojawiła się ona stosunkowo późno, w każdym razie znacznie później od właściwych tortur.

Jak się wydaje, sądy miejskie stosujące chlostę $w$ postępowaniu dowodowym wykorzystywały ją jednak w bardzo różnym stopniu. Często sięgano po ten środek w osiemnastowiecznym Krakowie. Na początku drugiej połowy tegoż stulecia chłostanie oskarżonych zdecydowanie przeważało nad "tradycyjnymi" torturami, polegającymi na wyciąganiu stawów i przypalaniu boków delikwenta ${ }^{22}$. Ale $w$ tym samym mniej więcej czasie w Tarnowie (lata 1750-1773) można się doliczyć zaledwie czterech przypadków orzeczenia chłosty $^{23}$, podczas gdy „,właściwe” tortury przeprowadzono aż w 11 sprawach $^{24}$.

${ }_{16}$ APKr. AMKr. 869, s. 144, 146 (1693), 300 (1694); APKr. AMKr. 870, s. 57-58 (1698), 107 (1698 - notatka słabo czytelna); APKr. AMKr. 871, s. 80 (1700).

${ }^{17} \mathrm{Z}$ tego okresu dysponujemy protokolem tylko jednej sprawy osądzonej w $1659 \mathrm{r}$. (APKr. AMKr. 897, s. 29-32).

${ }^{18}$ Możliwe, że takiej „probacyjnej” chłosty dotyczy niewyraźna notatka z roku 1683 (APKr. AMKr. 867, s. 116).

19 Zachowały się $\mathrm{z}$ tego okresu księgi: APKr. AMKr. 864 (lata 1554-1625), 865 (lata 1589-1604), 866 (lata 1630-1633).

${ }^{20}$ Należy jednak zaznaczyć, że przebadana księga spraw kryminalnych miasta Tarnowa (MTarn. MT-H 505) zawiera wpisy jedynie $z$ lat 1750-1773, zaś nasze wiadomości o praktyce przemyskiej ograniczają się do krótkiej wzmianki z 1734 r. (APPrzem. AMPrzem. 85, s. 38).

${ }^{21}$ APKr. IT 229h, s. 17.

${ }^{22} \mathrm{~W}$ trzecim ćwierćwieczu XVIII w. można ustalić zaledwie 31 przypadków zastosowania tortur, podczas gdy liczba orzeczeń nakazujących chłostę była niemal dwukrotnie wyższa. Szerzej na ten temat M. Mik ołajczyk, $Z$ dziejów wymuszania..., s. 89-90, zwłaszcza przyp. 18 i 21.

${ }^{23}$ Zob. MTarn. MT-H 505, k. 33-33v. (1756), 65v.-66 (1763), 96v.-97 (1771). W jednym przypadku chłosta została orzeczona jako kara, ale przy okazji miała służyć „wydobyciu” zeznań (MTar. MT-H 505, k. 66v.-67v. (1764)).

${ }^{24}$ MTarn. MT-H 505, k. 7v. -8 (1754), 11-11v. (1754), 15v.-16 (1754), 18v. (1754), 21v, -23 (1754), 40v.-41 (1758), 52v.-55 (1761), 58-58v. (1762), 63v.-64 (1762), 77v.-78v. (1765), 113-116v. (1772). Być może torturom poddano też oskarżoną, o której w 1757 r. zapisano, iż powinna aby być per executorem iustitiae spróbowana (MTarn. MT-H 505, k. 34). 
Również w Nowej Górze przeshuchiwania za pomocą rózg odnotowano jedynie w latach 1752 i $1754^{25}$, jednak - rzecz ciekawa - byl to wtedy już jedyny sposób wymuszania zeznań. W protokołach $\mathrm{z}$ lat pięćdziesiątych i sześćdziesiątych XVIII w. nie ma bowiem mowy o torturach, choć wcześniej w miasteczku były one dość często stosowane ${ }^{26}$. Być może nowogórscy sędziowie wciąż mieli $w$ pamięci skierowane do nich słowa właściciela miasta Augusta Aleksandra Czartoryskiego, który w związku z rozpatrywaną w 1737 r. sprawą kryminalną podkreślil, iż korporalne konfesaty w glównych tylko $i$ wielkiej konsekwencyi kryminalach naznaczać sie zwykly, sugerując w ten sposób ostrożność w ich wykorzystywaniu ${ }^{27}$.

3. Chłostę stosowano w sprawach o bardzo różne czyny. Bito więc przede wszystkim podejrzanych o popełnienie przestępstw przeciwko mieniu: kradzieży, przywłaszczenia, paserstwa ${ }^{28}$, ale także oskarżonych o ucieczkę ze służby ${ }^{29}$, o cudzołóstwo ${ }^{30}$, powtarzanie chrztu ${ }^{31}$, podpalenie ${ }^{32}$, zabójstwo ${ }^{33}$ i dzieciobójstwo $^{34}$. Za pomocą chłosty starano się niekiedy zmusić oskarżonych do przyznania się do winy ${ }^{35}$, częściej jednak poddawano owej próbie osoby,

${ }^{25}$ APKr. IT $229 \mathrm{~h}$, s. $17,18$.

${ }^{26}$ Np. APKr. IT 229b, s. 20 (1679), 45 (1681), 119-120 (1686), 133-134 (1687), 157 (1688), 162 (1688); APKr. IT 229g, s. 10-11 (1677), 15 (1677), 19-20 (1677), 27 (1678), 73-74 (1698), 89 (1699), 97 (1701), 111-113 (1704); BJ 122, k. 6-6v. (1737), 11 (1749).

${ }^{27}$ BJ 122, k. 7. Zauważmy, że w 1749 r. sąd nowogórski, decydując o zastosowaniu tortur, zwrócil się z prośbą do komisarza dóbr o zatwierdzenie owego postanowienia (BJ 122, k. 11).

${ }^{28}$ Np. APKr. AMKr. 875, s. 34 (1735); APKr. AMKr. 878, s. 25-26 (1744), 114 (1744); APKr. AMKr. 879, s. 37-38 (1746); APKr. AMKr. 880, s. 80 (1750), 139 (1751); APKr. AMKr. 881, s. 34 (1753), 79 (1754), 110 (1754), 128-129 (1755), 133 (1755), 181-182 (1756); APKr. AMKr. 882, s. 79-80 (1758); APKr. AMKr. 883, s. 13 (1763), 83 (1765), 200 (1766), 204 (1766); APKr. AMKr. 884, s. 33-34 (1775), 116 (1776); APKr. AMKr. 885, s. 126, 232-234 (1777), 289-290 (1777), 302 (1777); APKr. AMKr. 887, s. 49 (1780); APKr. AMKr. 892, s. 98-99 (1787), 114-115 (1787); APKr. AMKr. 897, s. 383-384 (1773); APKr. AMKaz. K 276, s. 87-91 (1787); APKr. IT 229h (Nowa Góra), s. 18 (1754); MTarn. MT-H 505 (Tarnów), k. 33v. (1756). Chłostę stosowano także w przypadku oskarżeń o świętokradztwo - por. APKr. AMKr. 883, s. 359-360 (1768); APKr. AMKr. 884, s. 73 (1775).

${ }^{29}$ APKr. AMKlep. KL 70, s. 27-28 (1783).

${ }^{30}$ APKr. IT 229h (Nowa Góra), s. 17 (1752); ATarn. MT-H 505 (Tarnów), k. 65v.-66 (1763), 96-97 (1771).

${ }^{31}$ APKr. AMKr. 881, s. 138 (1755).

${ }^{32}$ APKr. AMKr. 884, s. 9, 18 (1774).

${ }_{33}$ APKr. AMKr. 883, s. 62 (1764); APKr. AMKr. 886, s. 51-52 (1778).

${ }^{34}$ APKr. AMKr. 884, s. 167, 171-172 (1776); APKr. AMKr. 897, s. 359-360 (1766).

${ }^{35}$ APKr. AMKr. 878, s. 25-26 (1744), 223-225, 226-227 (1745); APKr. AMKr. 883, s. 83 (1765), 374, 376 (1769); APKr. AMKr. 884, s. $42-43$ (1775), 163, 167, 171-172 (1776); APKr. AMKr. 886, s. 51-52 (1778); MTarn. MT-H 505 Tarnów), k. 33-33v. (1756). 
które nie zaprzeczały, że popełniły przestępstwo, ale można było przypuszczać, iż ukrywają pewne fakty, zaniżają szkody wyrządzone swoim czynem ${ }^{36}$. Nieraz $\mathrm{w}$ ten właśnie sposób próbowano zebrać informacje o zamieszanych w sprawę wspólnikach ${ }^{37}$. Z drugiej strony - oczekiwano, że odebrane przez oskarżonego plagi pozwolą zweryfikować złożone wcześniej przez niego dobrowolne zeznania, wykluczyć niesłuszne pomówienia ${ }^{38}$. Cele stawiane przed chłostą nie różniły się zatem od zadań, które spelniały „właściwe” tortury.

4. O poddaniu obwinionego chloście decydował sąd. Odpowiednie postanowienia wydawane były na wniosek oskarżyciela ${ }^{39}$, aczkolwiek zdarzały się chyba również decyzje podejmowane $\mathrm{z}$ urzędu ${ }^{40}$. W dekretach owych dokładnie nieraz określano nie tylko cel przesłuchania, ale także czas, miejsce i sposób jego przeprowadzenia.

Zdarzało się, że oskarżonego poddawano chłoście natychmiast po decyzji sądu. W Tarnowie, przynajmniej w niektórych sprawach plagi wymierzano

${ }^{36}$ Por. APKr. AMKr. 869, s. 144 (1693); APKr. AMKr. 878, s. 116 (1744); APKr. AMKr. 879, s. 14 (1746), 37-38 (1746); APKr. AMKr. 880, s. 160 (1751), 190 (1752), 189 (1752), 224 (1752); APKr. AMKr. 881, s. 134 (1755); APKr. AMKr. 882, s. 31-32 (1758), 45-46 (1758); APKr. AMKr. 884, s. 227 (1776), 251 (1776), 119-120 (1777); APKr. AMKr. 886, s. 131-132 (1779); APKr. AMKr. 887, s. 49 (1780); APKr. AMKr. 892, s. 98-99 (1787).

${ }^{37}$ Tak np. APKr. AMKr. 878, s. 116 (1744); APKr. AMKr. 879, s. 14 (1746); APKr. AMKr. 880, s. 82 (1750), 107 (1751), 160 (1751), 189 (1752), 190 (1752); APKr. AMKr. 882, s. 31-32 (1758), 45-46 (1758), 275-276 (1761), 286-287 (1762), 336 (1763); APKr. AMKr. 883, s. 268 (1767); APKr. AMKr. 887, s. 174 (1781); APKr. IT 229h (Nowa Góra), s. 17 (1752), 18 (1754).

${ }^{38}$ Tak zwłaszcza w Tarnowie. W 1763 r. chłosta orzeczona wobec Reginy Czerwienionki miała potwierdzić jej zeznanie dotyczące współuczestnika zbrodni cudzołóstwa, o którą była oskarżona (MTarn. MT-H 505, k. 65v.-66). W następnym roku próbowano w ten sposób ustalić, na ile prawdziwe są zeznania kobiety zarzucającej księdzu Wawrzyńcowi Mrozieńskiemu, iż popełnił z nią cielesny uczynek (MTarn. MT-H 505, k. 66v.-67v.). Podobnie, dla potwierdzenia wcześniejszych zeznań wychłostano w $1771 \mathrm{r}$. Zofię Daniszewską (MTarn. MT-H 505, k. 96-97).

${ }^{39}$ Np. w 1694 r. w Krakowie oskarżyciel stwierdzając, iż aresztant właściwie powinien pójść na meki, prosił jednak, aby tylko byl próbowany rózgami (APKr. AMKr. 869, s. 300). Wnioski nie zawsze chyba były uwzględniane. W tym samym mieście, w $1698 \mathrm{r}$., choć strona powodowa domagała się zastosowania chłosty, sąd nakazał oskarżonej złożyć jedynie przysięgę oczyszczającą (APKr. AMKr. 870, s. 57-58). Zob. też przypadki zastosowania przez sąd chlosty zamiast proponowanych tortur (por. przyp. 8).

* Tak zapewne w $1756 \mathrm{r}$. w Tarnowie. Sąd zważywszy między stronami kontrowersyje i to, że oskarżony żadnym sposobem nie chce się przyznać, choć są wyraźne przeciw niemu dowody, uznał, iż powinien być cieleśnie piqúdziesiqt rózg spróbowany (MTarn. MT-H 505, k. 33-33v.). Podobnie w 1763 r. (MTarn. MT-H 505, k. 65v.-66) i 1771 r. (MTarn. MT-H 505, k. 96v.-97). Zob. też APKr. IT 229h (Nowa Góra), s. 18 (1754). 
na sali ratusznej, i to in instanti ${ }^{41}$. Podobnie - jak się wydaje - postępowano w Nowej Górze ${ }^{42}$.

W Krakowie sposób procedowania był chyba jednak inny. Wszystko wskazuje na to, że dla przeprowadzenia chlosty przerywano na jakiś czas rozprawę; w postanowieniach sądu wspominano zresztą o zawieszeniu ostatecznego rozstrzygnięcia ${ }^{43}$. Ponadto zaznaczano czasem, że obwinionych przesluchiwać ma hutman ratuszny (capitaneus praetorii) ${ }^{44}$, a więc nie sąd. Nieraz podkreślano też, że próba powinna się odbywać w obecności oskarżyciela (delatora) ${ }^{45}$ lub jego pełnomocnika ${ }^{46}$, a niekiedy polecano stronie powodowej, by wcześniej przygotowała listę pytań, na które powinien odpowiedzieć poddany badaniu oskarżony ${ }^{47}$. Najwyraźniej więc $w$ królewskim i stołecznym Krakowie nie było miejsca dla improwizacji; wszystko przebiegało wolniej, ale za to zgodnie $\mathrm{z}$ ustalonymi zwyczajowo regułami.

Obecność hutmana podczas przesłuchań wskazywałaby, iż w Krakowie chlostę wykonywali podlegli mu pachołkowie miejscy ${ }^{48}$. Notatka z $1773 \mathrm{r}$. wyraźnie zresztą wspomina o biciu oskarżonej przez sługe ratuszowego ${ }^{49}$. W Tarnowie w $1771 \mathrm{r}$. zaznaczono, iż rózgi mają być wymierzone przez bedella miejskiego ${ }^{50}$, czyli przez tamtejszego woźnego. Podobnie było chyba

${ }^{41}$ Tak w 1771 r. (MTarn. MT-H 505, k. 96v.). Na sali miała też odebrać plagi oskarżona sądzona w roku 1763. Również w tym wypadku najwyraźniej nie przerywano rozprawy dla przeprowadzenia próby (MTarn. MT-H 505, k. 65v.-66). W jeszcze innej sprawie obwiniony chyba też niezwłocznie został cieleśnie [...] spróbowany, ale - jak zarządził sąd - zaraz po wychłostaniu miał zostać odesłany do aresztu (MTarn. MT-H 505, k. 33v.).

\$2 Por. fragmenty protokolów: ...która i tu poczela sie ekskuzować, że to nie z tymże Kleczkiem, ale z biegunem jakimsi, lecz gdy znowu onę wyprowadzono $i$ rózgami dobrze chlostano, na tegoż samego Kleczka powiedziala (APKr. IT 229h, s. 17 (1752)); tak tedy inaczej nie można bylo dość prawdy, naznaczono mu dać rózgami plag sto, którego kiedy bito, przestajqc pytano, $z$ kim kradl. Ponieważ oskarżony pomawiał o współudział $w$ kradzieży niejakiego Piotra Pikułe, przeto wziço po tym, po inkwizycyi Piotra Pikule pod rózgi... (APKr. IT 229h, s. 18 (1754)).

${ }^{43} \mathrm{~Np}$. W 1787 r. sąd nakazał wychlostanie oskarżonego suspensa decisione finali (APKr. AMKr. 892, s. 99). Zob. też APKr. AMKr. 885, s. 120 (1777); APKr. AMKr. 887, s. $151-152$ (1781).

14 APKr. AMKr. 869, s. 144 (1693); APKr. AMKr. 879, s. 14 (1746); APKr. AMKr. 881, s. $128-129$ (1754).

45 APKr. AMKr. 878, s. 114 (1744); APKr. AMKr. 882, s. 2-3 (1757); APKr. AMKr. 887, s. 151-152 (1781).

46 APKr. AMKr. 878, s. 226-227 (1745) i chyba podobnie w 1779 r. (APKr. AMKr. 886, s. 131-132).

47 APKr. AMKr. 883, s. 54 (1764); APKr. AMKr. 884, s. $42-43$ (1775); APKr. AMKr. 885, s. 289-290 (1777); APKr. AMKr. 887, s. 49 (1780).

${ }^{18}$ Zob. J. K racik, M. R ożek, Hultaje, zloczyńcy, wszetecznice w dawnym Krakowie. O marginesie spolecznym XVI-XVIII w., Kraków 1986, s. 58-59.

${ }^{49}$ APKr. AMKr. 897 , s. 384.

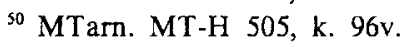


i $w$ innych miastach. W każdym razie mało prawdopodobne wydaje się (choćby ze względu na wyższe koszty), by angażowano do tej czynności kata bądź jego pomocników.

Oskarżonych bito najczęściej rózgami ${ }^{51}$, czasem także biczem (disciplina) ${ }^{52}$ lub kijem (baculus) $)^{53}$, przy czym sąd zazwyczaj z góry określał liczbę razów, które przesłuchiwany miał otrzymać. Wahała się ona od 15 aż do $450^{54}$, przy czym w przypadku większej liczby uderzeń - przynajmniej w Krakowie i sąsiednim Kazimierzu - zarządzano nieraz wymierzanie ich ,na raty". I tak np. w 1754 r. sąd krakowski uznał, że oskarżony Sebastian Żabicki powinien być virgis per 40 optimis binis vicibus probandum, zaznaczając przy tym, iż pierwszą porcję powinien odebrać tego samego dnia, zaś następną - w najbliższy poniedziałek ${ }^{55}$. Sądzonego w 1779 r. Kacpra Piątkowskiego bito aż pięciokrotnie, wymierzając mu jednorazowo po 50 uderzeń $^{56}$. Była

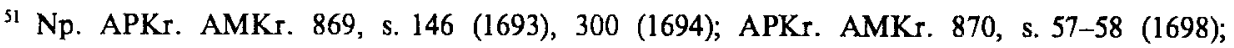
APKr. AMKr. 871, s. 80 (1700); APKr. AMKr. 878, s. 24 (1744), 97 (1744), 114 (1744); APKr. AMKr. 879, s. 14 (1746), 37-38 (1746); APKr. AMKr. 880, s. 139 (1751), 160 (1751), 224 (1752); APKr. AMKr. 881, s. 110 (1754), 134 (1755), 247 (1757); APKr. AMKr. 882, s. 45-46 (1758); APKr. AMKr. 883, s. 13 (1763), 83 (1765), 246 (1767); APKr. AMKr. 884, s. 33-34 (1775); APKr. AMKr. 885, s. 234 (1777); APKr. AMKr. 887, s. 151-152 (1781); MTarn. MT-H 505 (Tarnów), k. 33v. (1756), 65v.-66 (1763).

${ }_{52}$ APKr. AMKr. 885, s. 294 (1777); APKr. AMKr. 887, s. 49 (1780).

53 APKr. AMKr. 880, s. 82 (1750).

${ }^{54}$ Np. 15 uderzeń: APKr. AMKr. 881, s. 247 (1757); APKr. AMKlep. KL 70, s. 28 (1783), 20: APKr. AMKr. 885, s. 296 (1777), 30: APKr. AMKr. 871, s. 80 (1700); APKr. AMKr. 881, s. 128-129 (1755), 133 (1755); APKr. AMKr. 882, s. 206 (1760); APKr. AMKr. 887, s. 432-433 (1781); MTarn. MT-H 505 (Tarnów), k. 65v.-66 (1763), 50: APKr. AMKr. 880, s. 80 (1750); APKr. AMKr. 881, s. 110 (1754); APKr. AMKr. 882, s. 165 (1760), 336 (1763); APKr. AMKr. 884, s. $42-43$ (1775), 251 (1776); APKr. AMKr. 885, s. 120 (1777), 294 (1777); APKr. AMKaz. K 278, s. 28 (1790); MTam. MT-H 505 (Tarnów), k. 33v. (1756), 60: APKr. AMKr. 885, s. 289-290 (1777); MTarn. MT-H 505 (Tarnów), k. 97 (1771), 80: APKr. AMKr. 881, s. 79 (1754); APKr. AMKr. 882, s. 79-80 (1758), 100: APKr. AMKr. 878, s. 24 (1744), 226-227 (1745); APKr. AMKr. 883, s. 376 (1769); APKr. AMKr. 884, s. 9 (1774), 73 (1775), 116 (1776); APKr. IT 229h (Nowa Góra), s. 18 (1754), 200: APKr. AMKr. 886, s. 51-52 (1778), 250: APKr. AMKr. 886, s. 131-132 (1779); APKr. AMKr. 892, s. 114-115 (1787), 300: APKr. AMKaz. K 275, s. 30-31 (1779); APKr. AMKaz. K 276, s. 87-88 (1787), 450: APKr. AMKr. 880, s. 190 (1752). W niektórych sprawach różnicowano liczbe uderzeń, które miały spaść na plecy poszczególnych oskarżonych. W $1744 \mathrm{r}$. w Krakowie jeden $z$ podejrzanych o kradzież miał więc dostać 100 plag, drugi 50, a trzeci tylko 20 (APKr. AMKr. 878, s. 97). W 1758 r. w tym samym mieście dwaj oskarżeni mieli być poddani trzykrotnej chłoście, przy czym Kwiatkowski miał za każdym razem otrzymywać po 50 uderzeń, a Korczyński po 20 (APKr. AMKr. 882, s. 31-32).

s5 APKr. AMKr. 881, s. 79.

${ }^{\text {s6 }}$ APKr. AMKr. 886, s. 131-132 (1779). 
to częsta praktyka ${ }^{57}$; o wiele rzadziej natomiast nakazywano powtarzanie chlosty, gdy pierwsza próba okazała się nieskuteczna ${ }^{58}$.

Nie wszystkie postanowienia sądu zawierały wyraźne określenie liczby plag. Zdarzały się dekrety bardziej ogólnikowe, stwierdzające jedynie, że obwiniony ma być per plagis probandum ${ }^{59}$. Możliwe, że w takich wypadkach wymierzano jakąś zwyczajowo przyjętą liczbę uderzeń, niewykluczone jednak, że bito wówczas aż „do skutku”. Oto bowiem w 1735 r. w Krakowie sąd radziecki uznal, iż oskarżona o kradzieże kobieta ma być virgis quinquaginta et ultra [podkreśl. moje - M. M.] probandam ${ }^{60}$.

Niezależnie od wcześniej złożonych wyjaśnień, przed samą chłostą oskarżony był jeszcze raz przesłuchiwany, chociaż nie mamy pewności, czy była to praktyka powszechna ${ }^{61}$. Niewątpliwie pilnie słuchano też wszystkiego, co obwiniony mówił później: już podczas wymierzania mu plag. W Krakowie, w sporządzanych tam bardzo dokładnych protokołach $\mathrm{z}$ takich przesłuchań odnotowywano każde słowo oskarżonego, nawet prośby i zaklęcia wykrzykiwane pod wplywem bólu ${ }^{62}$. Nie wiadomo natomiast, czy oskarżonego bito i wypytywano równocześnie. Bardzo moźliwe, że postępowano tak jak

${ }^{57}$ Por. np. APKr. AMKr. 880, s. 82 (1750 - 3 razy, ale bez podania liczby uderzeń), 160 (1751 - 3 razy, podobnie bez liczby plag), 190 (1752 - $3 \times 150)$; APKr. AMKr. 881, s. $158-159(1755-3 \times 30), 163(1755-2 \times 30)$; APKr. AMKr. 882, s. $17(1757-$ per tres dies probandum), $111(1759-3 \times 20)$; APKr. AMKr. 883, s. $54(1763-3 \times 30)$, 278-279 (1763 - virgis optimis ter probandum); APKr. AMKr. 884, s. 33-34 (1775 - plagis 100 binis vicibus per plagas 50), 227 (1776 - $2 \times 50)$; APKr. AMKr. 887, s. $49(1780$ $-2 \times 50$ ); APKr. AMKr. 892, s. 98-99 (1787- $4 \times 25), 114-115(1787-5 \times 50)$; APKr. AMKaz. K 276, s. 88 (1787-3 × 100); APKr. AMKaz. K 278, s. 120-121 (1793-2 2 25).

${ }^{\text {s8 }} \mathrm{W} 1779 \mathrm{r}$. w Krakowie kazano wymierzyć 100 dodatkowych uderzeń oskarżonemu, który nie poszerzył zeznań po pierwszych pięćdziesięciu plagach (APKr. AMKr. 885, s. 119-120, 126). Zob. też APKr. AMKr. 875, s. 34, 45 (1735); APKr. AMKr. 878, s. 25-26, 29 (1744); APKr. AMKr. 885, s. 232-234 (1777).

${ }^{59}$ Np. APKr. AMKr. 878, s. 71-72 (1744); APKr. AMKr. 879, s. 14 (1746); APKr. AMKr. 880, s. 107 (1751), 224 (1757); APKr. AMKr. 882, s. 14 (1757). Zob. też przyp. 57.

${ }^{60}$ APKr. AMKr. 875, s. 34.

${ }^{61}$ Protokoły sporządzane $\mathrm{w}$ Krakowie wyraźnie dzieliły przeshuchania na examen ante plagas i późniejszy etap, już z użyciem rózg (por. APKr. AMKr 897, s. 359-360 (1766), 363 (1768), 383-384 (1773), 629-632 (brak daty)). Zob. też APKr. AMKr. 878, s. 129-131 (1744); APKr. AMKr. 884, s. 9 (1774).

${ }^{62}$ W 1766 r. przeshuchiwano tam Mariannę Nowakównę podejrzaną o dzieciobójstwo. Obwiniona uparcie twierdziła, że jej dziecko urodziło się nieżywe. W protokole zapisano: Tandem virgis probata. Umierać gotowam, jako nieżywe. Powtórnie. Nieżywe, nieżywe, na Rany Boga zaklinam, jako nieżywe bylo, nie wiedzial o tym nikt, bo sama nie wiedzialam, co sie ze mnq dzieje. Stoje przy tym wszystkim, com powiedziala $i$ to jest prawda wszystko, com zeznala. Tertio virgis probata. Święty Józefie, święty Antoni ratuj mnie, na Rany Boga zaklinam. choćby mnie zabić WPan kazal, inaczej nie powiem (APKr. AMKr. 897, s. 359-360). 
w Nowej Górze w 1754 r., kiedy to kilkakrotnie przerywano chłostę i zadawano oskarżonemu pytania ${ }^{63}$.

W sumie przebieg posteppowania był zbliżony do przesłuchania na torturach ${ }^{64}$. Warto zreszta dodać, że i w przypadku chlosty domagano się od oskarżonych późniejszego dobrowolnego potwierdzenia zeznań złożonych pod wplywem bólu ${ }^{65}$.

5. Chociaż chłosta stosowana $w$ trakcie procesu miała na celu wymuszenie zeznań, to jednak sędziowie miejscy zdawali sobie niewątpliwie sprawę $\mathrm{z}$ jej znacznej dolegliwości i nieraz starali się to uwzględniać w końcowym wyroku. Zdarzalo się zatem, że zaliczano odebrane wcześniej rózgi na poczet kary i odpowiednio lagodzono sankcję ${ }^{66}$. Postępowano zatem podobnie, jak w przypadku zaliczanego na rzecz kary więzienia aresztu tymczasowego ${ }^{67}$, ale także klasycznych tortur, których zastosowanie nieraz wpływało na złagodzenie ostatecznego orzeczenia ${ }^{68}$.

Nie był to jednak jedyny związek procesowej chłosty $\mathrm{z}$ karą. Zdarzało się bowiem, choć raczej rzadko, ze bicie w celach dowodowych lączono $\mathrm{z}$ wyrokiem skazującym. Zapadaly zatem orzeczenia, w których nakazywano wymierzyć złoczyńcy karę chłosty, a przy okazji jeszcze go wypytać o to, czego $w$ trakcie procesu nie udało się ustalić ${ }^{69}$.

${ }^{63}$ Naznaczono mu dać rózgami plag sto, którego kiedy bito, przestajqc pytano z kim kradl, po kilka razy tego bylo, a za każdym pytaniem tylko na tego Piotra Pikulę [wskazywal]" (APKr. IT 229h, s. 18). Na przerwy w biciu wskazuje też krakowski protokół z $1766 \mathrm{r}$. (por. przyp. poprzedni).

${ }^{64}$ Por. W. M a is el, Tortury..., s. 118-120.

${ }^{65}$ Por. APKr. AMKr. 897, s. 363-364 (1768); MTarn. MT-H 505, s. 65v.-66 (1763), 96-97 (1771).

${ }^{66} \mathrm{~W} 1754$ r. w Nowej Górze sąd nakazal, aby bity w śledztwie Szymon Dura, okrom tych pierwszych stu plag rózgami odebranych, byl karany pięciqdziesiqt i zakazem pobytu $\mathrm{w}$ mieście (APKr. IT 229h, s. 17-18). W 1771 r. w Tarnowie uznano, że oskarżonej trzeba wymierzyc mniejszą karę, ponieważ na korporalnych inkwizycjach próbowana byla (MTarn. MT-H 505, k. 97). Zob. też przykłady z Krakowa: APKr. AMKr. 881, s. 181-182, 184 (1756); APKr. AMKr. 885, s. 234 (1777); APKr. AMKr. 887, s. 119 (1781), 433 (1781); APKr. AMKr. 892, s. 81 (1787), 195-196 (1789) i Kleparza: APKr. AMKlep. KL 70, s. 27-28 (1783). W $1780 \mathrm{r}$. w Krakowie sąd uwzględnił nawet nieformalne dręczenie oskarżonego, którego żołnierze przez trzy dni kańczugami bili a wodq polewali (APKr. AMKr. 887, s. 58, 73).

${ }^{67}$ Zob. M. M ikołajcz yk, Przestepstwo i kara w prawie miast Polski poludniowej XVI-XVIII wieku, Katowice 1998, s. 147.

${ }^{68} \mathrm{~Np}$. w 1709 r. sąd w Krakowie torturas etiam in poena computando skazał oskarżonego na ścięcie głowy i póżniejsze ćwiartowanie (APKr. AMKr. 872, s. 62-63). Zob. też APKr. AMKr. 870, s. 37-38 (197); APKr. AMKr. 872, s. 509 (1716).

${ }^{64}$ Tak oto w $1716 \mathrm{r}$. w Krakowie sąd uznał oskarżoną za złodziejkę i skazal ja na chłostę. Podczas bicia miano ją dodatkowo wypytać o skradzione pieniądze, których nie udało się odzyskać (APKr. AMKr. 872, s. 385-386). W 1761 r. innego złodzieja ukarano pobytem $w$ domu poprawy i chłostą, która miała pomóc bodajże $w$ schwytaniu współsprawcy 
6. Pozostaje jeszcze jedna kwestia. Uchwalona 23 października $1776 \mathrm{r}$. konstytucja sejmowa zakazała - jak wiadomo - stosowania tortur, nie przewidując w dodatku żadnych zastępczych środków przymusu. Prowadzone przez nas kilka lat temu badania nad praktyką sądową w osiemnastowiecznym Krakowie pozwoliły jednak stwierdzić, że choć po $1776 \mathrm{r}$. w mieście tym właściwych tortur już nie stosowano, to aż do końca lat osiemdziesiątych XVIII w. bito oskarżonych, których podejrzewano o zatajanie prawdy ${ }^{70}$. Jak się okazuje, podobnie działo się $w$ obu sąsiadujących z Krakowem miastach: Kazimierzu ${ }^{71}$ i Kleparzu ${ }^{72}$. Co więcej, o ile w przypadku Krakowa ostatnia wzmianka o chłoście pochodzi $\mathrm{z}$ roku $1789^{73}$, to w Kazimierzu postanowienia o poddaniu oskarżonego tej próbie zapadały aż po rok $1793^{74}$. Przedwczesny i zbyt optymistyczny okazal się zatem wyciągnięty przez nas kiedyś wniosek o zanikaniu chłosty procesowej w ostatnich latach I Rzeczypospolitej ${ }^{75}$.

7. O chłoście jako środku przymusu wobec oskarżonego, wykorzystywanym niezależnie od tortur, informują jedynie dokumenty praktyki, dawne miejskie księgi sądowe. Pozwalają one na w miarę dokładne odtworzenie reguł procesowych odnoszących się do chlosty, a zwlaszcza sposobu jej wykonania.

Wiele pytań pozostaje jednak bez odpowiedzi. Fragmentaryczne wciąż badania nie pozwalają na ustalenie, czy stosowanie chlosty w postępowaniu dowodowym było zjawiskiem powszechnym, charakterystycznym dla całej ówczesnej Rzeczypospolitej, czy ograniczało się tylko do Małopolski. Nie potrafimy też wytłumaczyć, dlaczego $w$ jednych miastach środek ten był wykorzystywany, podczas gdy $w$ innych najprawdopodobniej $w$ ogóle po niego nie sięgano.

Wszystko wskazuje na to, iż bicie oskarżonych w celu wymuszenia od nich zeznań pojawiło się późno, być może dopiero w drugiej połowie

przestępstwa (APKr. AMKr. 882, s. 233-234). Z kolei w Tarnowie w 1764 r. sąd za popelniony cielesny uczynek, tudzież dla lepszego dowiedzenia się od niej, z kim sie dopuścila tegoż uczynku, nakazał oskarżonej wymierzyć trzykrotnie po 50 plag. Ostatecznie, nie mogqc się dowiedzieć rzeczywistości, darowano jej trzecią ratę chłosty (MTarn. MT-H 505, k. 67-67v.). Zob. też przykład z Kleparza: APKr. AMKlep. KL 69, s. 347 (1776).

${ }^{70}$ Por. np. APKr. AMKr. 886, s. 51-52 (1778), 131-132 (1779); APKr. AMKr. 885, s. 93 (1777), 126 (1777), 294 (1777), 302 (1777); APKr. AMKr. 887, s. 49 (1780), 151-152 (1781), 432-433 (1781); APKr. AMKr. 892, s. 98-99 (1787), 114-115 (1787), 195-196 (1789). Szerzej na ten temat: M. Mikołajczyk, $Z$ dziejów wymuszania..., s. $90-94$.

7 APKr. AMKaz. K 275, s. 30-31 (1779), 53-54 (1780), 108 (1781), 110 (1781), 206 (1784); APKr. AMKaz. K 276, s. 87-88 (1787), 89-91 (1787); APKr. AMKaz. K 278, s. 28 (1790).

72 APKr. AMKlep. KL 70, s. 27-28 (1783).

${ }^{73}$ APKr. AMKr. 892, s. 195-196.

${ }^{74}$ APKr. AMKaz. K 278, s. 28 (1790), 120-121 (1793).

${ }^{75}$ M. Mikołajczyk, $Z$ dziejów wymuszania..., s. 94. 
XVII w. Nie wiemy jednak, dlaczego obok tradycyjnych tortur zaczęto wtedy stosować nowy, mniej drastyczny sposób prowadzenia przesłuchań. Być może wiązało się to $\mathrm{z}$ postępującym wówczas lagodzeniem prawa karnego materialnego; skoro za niektóre przestępstwa zaczęto orzekać lżejsze niż dotychczas kary, to trudno było w sprawach o te czyny stosować tortury przewyższające okrucienstwem finalne rozstrzygnięcie.

Nie do końca rozwiązany pozostaje wreszcie problem zaniku chlosty jako formy wymuszania zeznań. Udało się co prawda ustalić, że w Krakowie i sąsiednich miastach nie zaniechano bicia oskarżonych także po uchwaleniu konstytucji sejmowej zabraniającej stosowania tortur. Dalej jednak nie wiadomo, czy stosowane w latach osiemdziesiątych i dziewięćdziesiątych XVIII w. namiastki tormentów miały ogólnopolski zasięg, czy też może było to tylko lokalne zjawisko, ograniczone do Krakowa i jego miast satelickich. Być może dalsze badania nad prawem miejskim pozwolą rozwiązać $i$ to zagadnienie. 